\title{
Implementation of Customer Communication to Maintain the Hospital Image from the Issues of Coviding Patients
}

\author{
${ }^{1}$ Rain Gunawan, ${ }^{2}$ Muhamad Isnaini \\ ${ }^{1}$ Magister Ilmu Komunikasi Universitas Budi Luhur, Jl. Ciledug Raya No.99, Jakarta, Indonesia. \\ ${ }^{2}$ Magister Ilmu Komunikasi Universitas Bunda Mulia, Jl. Ancol Barat IV, Jakarta, Indonesia. \\ E-mail: ${ }^{1}$ raditya521@gmail.com, ${ }^{2}$ emisnaini@gmail.com
}

\begin{abstract}
Accusations of hospitals that have taken Indiscipline's actions on Covid-19 cases have many comments that's appeared on social media like Twitter with the hashtag \#BongkarMafiaCovidRS which reached 5,700 tweets. This study aims to examine the accusations of this issue, how the issue started and how to dismiss it. This research is a qualitative research using literature method. To complement the results of this study, the researcher also conducted interviews with several informants from medical personnel who worked in the hospital. Does the issue of coviding patients make the hospital's image worse? How is the hospital able to maintain the image of the hospital as a good health service facility amid accusations of coviding patients? The results of this study indicate that the developing issue is not based on facts, the hospital has clear SOPs and guidelines in carrying out covid-19 patient care. The hospital also conducts and implements customer communication to patients and patients'families before the procedure so that patients and families are well educated. Implementation of customer communication is one of the strategies that are believed to be able to maintain the hospital image and ward off accusations of the issue of coviding patients.
\end{abstract}

Keywords: Covid-19 Infodemic, Hospital Brand Image, Customer Communication

\section{INTRODUCTION}

Currently the Indonesian people, even parts of the world, are overwhelmed in the face of the Coronavirus Disease - 19 (COVID-19) pandemic. The disease, which is transmitted by the corona virus, has been declared a pandemic by the world health organization (WHO) on March 11, 2020, and is a threat to all countries in the world. In the Indonesian state, cases of Covid-19 that were confirmed positive continue to creep up, and this number is increasing. No wonder the central and local governments have made many efforts to stop the progress of the COVID-19 case. In addition to implementing the $3 \mathrm{M}$ (Wearing Masks, Keeping Distance and Washing Hands with Soap) movement program, the
Large-Scale Social Restriction Program (PSBB) through the Minister of Health Regulation Number 9 of 2020 dated April 3, 2020, the Government has also designated 132 hospitals to become hospitals. Covid-19 reference.

Seeing the development of news circulating on social media and the mass media in the country regarding the handling of the Covid-19 pandemic, issues related to hospitals that coviding patients are one of the issues that have received many responses and comments by various levels of society ranging from health professional organizations such as the Indonesian Doctors Association (IDI), the Indonesian National Nurses Association (PPNI), health workers, the general public, as well as responses from individual 
observers of the world of health. One of them, as reported by republika.co.id edition of October 6, 2020, PPNI as a professional organization for Indonesian nurses, responded that taking this action is considered difficult because handling health in hospitals involves various sectors, this of course requires conspiracy very large. Analyzing fraud committed by health facilities related to the act of coviding someone in a hospital requires an extraordinarily difficult step because hospital services record all actions and examination results from the patient's admission to the hospital, services in the emergency unit, in his hospitalization, including laboratory examinations and also the doctor in charge of the patient (DPJP) was all recorded.

This issue also did not escape the attention of the Minister of Health, Terawan Agus Putranto. Reporting from the 21st October 2020 edition of republika.co.id, the Minister of Health stated that he had worked at the hospital and in the hospital there were workers who had a conscience to say things honestly. if yes have to say yes, and if did 'not just say no. A doctor also cannot arbitrarily convict a patient who died because of Covid-19.

Responses also came from hospitals who were hit by the issue. In the Indonesia Lawyers Club (ILC) TVOne event which was uploaded on the YouTube channel Tuesday, October 6, 2020, Dr. Rifa as Deputy Medical Director of the Islamic Hospital Ibnu Sina Pekanbaru denied that his party had coviding the patient. Handling of Covid-19 does require special treatment unlike handling ordinary cases because this disease is a new type of disease and no suitable drug / vaccine has been found to prevent the spread of this virus.

Of course, this oblique issue related to accusations of the hospital mafia has had its own impact on the image of the hospital in the eyes of the public. Kotler and Clarke (1987) state that the hospital brand image is a combination of beliefs, ideas and impressions that a patient or society has about a hospital. The brand image of a hospital is not absolute, but relative to competition between hospitals. Usually the patient and the patient's family form a brand image of a hospital based on the experience of the medical examination and treatment that they have gone through.

Hospital brand image has a strategic function. Through marketing strategy activities, a hospital's brand image can be useful for enhancing its competitive position. Therefore, the hospital brand image is useful for strengthening the intensity of patients in choosing a hospital (Wu, 2011). Image (brand image) is a valuable intangible asset of the company. A positive image enables a company to gain reputation value and competitive advantage. Porter and Claycomb (1997) state that a good image will increase customer satisfaction, service quality, loyalty, and repurchase intention.

According to the Law of the Republic of Indonesia number 44 of 2009 concerning Hospitals, Hospitals are health service institutions for the community with their own characteristics that are influenced by developments in health science, technological advances and socio-economic communities who must continue to be able to improve quality and affordable services. society in order to realize the highest health status. Hospitals are obliged to provide inpatient, outpatient, emergency services and provide complete health services through promotive, preventive, curative and rehabilitative services.

In providing services for Covid-19 patients, the hospital has guidelines based on the Letter of the Minister of Health number HK.01.07 / Menkes / 413/2020 
concerning guidelines for the prevention and control of the 2019 corona virus diseases (Covid-19). Given that Covid-19 is a type of disease that causes public health emergencies as well as nonnatural disasters that not only cause death but also cause considerable economic losses, Covid-19 is treated specifically considering that the antidote for drugs and vaccines has not been clearly found. This guideline applies to all hospitals in Indonesia, both government-owned and private hospitals.

As time has passed since the first covid-19 cases were found in March 2020 , currently the covid services in hospitals have experienced a significant shift in services with the discovery of mild, moderate and severe cases. Of course, hospitals, as health service providers, as the spearhead of health with existing health facilities and human resources, must work together and work hard to serve the community in guarding this Covid-19 pandemic. However, this is a bit tarnished by the issue of accusations that the hospital mafia has "coviding patients", which has received a lot of responses from health workers who are directly in the field.

Of course, this accusation has quite influenced the image of the hospital that provides Covid-19 services. Da Silva (2008) in Nurullah Hidajahningtyas (2013) states that a good image will be able to increase the success of a company and conversely a bad image will worsen the stability of a company. Istijanto (2005) suggests that a company that has a good image or reputation will encourage consumers to buy the products offered, enhance competitiveness, encourage employee morale, and increase customer loyalty. The image of the hospital has an impact on patient attitudes and behavior towards the hospital. If the information from the patient is good, it will cause a positive image, but on the contrary, if the information received is bad, it will cause a negative image. The image of the hospital has a function as a liaison and guardian of harmony with their customers (Wu, 2011). Wu's research (2011) shows that the image of the hospital has an influence, either directly or indirectly, on patient loyalty. This indicates that a good hospital image not only increases patient satisfaction through direct patient loyalty, but also increases patient satisfaction through increased perceived service quality, which in turn increases patient re-visit intention.

Darlina's research (2015) shows that the results of the analysis show that the variable company image has a positive effect on customer loyalty, that the provision of service quality has a significant effect on customer loyalty, and a significant effect between company image and service quality on customer loyalty. Service quality is the difference between customer expectations or their desires and their perceptions (Bayhaqi: 2006). Quality health services are services that are oriented towards the satisfaction of each health service user in accordance with the average satisfaction level of service users. Satisfaction is a situation where customer needs, wants and expectations can be met through a given product (Haffizurrachman, 2004).

Service user satisfaction can be accommodated well by the existence of good communication between service providers and service recipients. Within the hospital, communication can be established between doctors and patients, nurses and families of patients, between administrators and visitors to the hospital and others. This communication is a form of customer communication, where the doctor / nurse is the service provider and the patient / patient's family is the service recipient. Quoted from Muhammad Sholeh in his writing "How to build communication with 
customers", customer communication can be interpreted as an activity to convey information from sellers / marketers to customers in order to maintain existing relationships. If the relationship is maintained, the customer can continue to make purchases so that the sales impact increases. Customer Communications (Customers Communications) is done so that consumers are satisfied and want to return to buy or use the services of the seller.

According to Laswell, as quoted by Cangara in his introductory book on communication (2010), communication needs to pay attention to the elements of who is conveying, what is conveyed, through what channels, to whom and what effect. A doctor or nurse or hospital officer must understand what is being conveyed, who is being invited to communicate and also be able to estimate the effect of the communication, so that communication can be well established. Every customer who comes to the hospital has a different educational background, different economic factors and also a different character / temperament. For this reason, customer communication is very important needed to maintain the image of the hospital and also help to ward off lopsided issues related to accusations of the hospital mafia who covided patients.

Seeing the unique issue related to the accusation that the hospital has coviding patients, the author intends to examine what really happened to the emergence of this issue. How did this issue arise and once occupied trending on Twitter? and how customer communication can be used to maintain the image of the hospital amidst the ongoing demands for COVID-19 services. The author tries to find a picture based on data in the mass media, compares assumptions that appear in the media, looks for related literature and journals as well as policies issued by the central government, especially policies issued by the Ministry of Health in handling pandemics this Covid-19.

\section{METHOD}

This research is a type of qualitative research with data collection techniques using the library research method or literature review and interviews. Literature review is a description of the theory, findings and other research materials obtained from reference materials to be used as a research basis to formulate a clear frame of mind from the formulation of the problem under study. Literature reviews can be contents of reviews, summaries and author's thoughts about some literature sources (articles, books, slides, information from the Internet, etc.). As for the interview, considering that currently there is a Covid pandemic, the interview only takes place via telephone and the WhatsApp application. The informants selected were medical personnel at the hospital that the author was familiar with so that it was easy to collect data.

The data used in this research is secondary data, namely data obtained not from direct observation, but data obtained from sources in the form of books, articles, journals, news. The main source of data for this study was taken from the press website droneemprit.id with an article entitled Hospital Pinched, "Hospitals Between Covid-19 and Accusations of Many Hospital Mafia and Coviding Patients" dated October 5,2020 . The author also took references from several online newspaper portals including Republika.co.id, era .id, Suara. com, ayosemarang.com, detik.com, kompas.com, and beritamedia.id. Articles on the kawalcovid19 Instagram account and pandemic talks are also a source of reference for authors, and journals related to hospital services during the Covid-19 pandemic. The author also accesses policies that have been issued 
by the government online through official government websites such as kemkes. go.id, covid19.go.id, dephub.go.id and setkab.go.id. To support secondary data and for more ensuring the sharpness of the author's argument, the author also conducted interviews with medical personnel at a number of Covid-19 referral hospitals such as Persahabatan Hospital and Cipto Mangunkusumo Hospital.

\section{RESULTS AND DISCUSSION}

The government has issued a targeted policy for handling Covid-19, breaking the chain of transmission by finding infected people to treat and isolate. Dr. Achmad Yurianto stated that steps to find the source of transmission were carried out by monitoring people who had a history of traveling in the epicenter area and tracing the contacts of infected patients. The Ministry of Health has also published specific preparedness guidelines for dealing with the coronavirus. Guidelines are made with the adoption of the WHO Health Organization. The guidelines from WHO describe the triage process for identifying and sorting patients, immediate action for infection prevention and control, administration of therapy and monitoring, collection of specimens for laboratories, management of respiratory failure, management of shock, prevention of complications and special Covid-19 care.

If traced back, various efforts have been made by the government to protect the public from the spread of the corona virus. President Jokowi has stipulated Government Regulation (PP) number 21 of 2020 concerning LargeScale Social Restrictions (PSBB) and has been in effect since April 2020. Local governments that will implement the PSBB must go through the approval of the central government through the Minister of Health. The mechanisms and indicators for implementing PSBB at the regional level are regulated in detail in the Minister of Health Regulation number 9 of 2020 concerning PSBB Guidelines in the context of accelerating the handling of Covid-19. In May 2020, the Government has also issued an appeal not to go home for the community. The Minister of State Apparatus Empowerment and Bureaucratic Reform (MENPANRB) has also issued circular number 46 of 2020 which prohibits the state civil apparatus (ASN) from going home during the pandemic, while the Minister of Transportation issued Ministerial Regulation number 25 of 2020 concerning Control of Transportation during the homecoming period.

In connection with developments in handling Covid-19, the Ministry of Health has issued a Minister of Health Decree number HK.01.07 / Menkes / 382/2020 concerning Health Protocols for the public in public places and public facilities in the context of preventing and controlling Covid-19. And in fulfilling the need to increase the role of hospitals in the prevention of certain emerging infectious diseases, the Minister of Health of the Republic of Indonesia has issued a Minister of Health Decree number HK.01.07 / Menkes / 275/2020 dated 23 April 2020 concerning the establishment of a referral hospital for certain emerging infectious diseases. It was stated in the Ministerial Decree that hospitals that are referred to for handling certain emerging infectious diseases have the duty to manage suspected cases that have the potential for extraordinary events or outbreaks of certain emerging infectious diseases including the 2019 coronavirus release (COVID-19) and provide referral health services for patients and reference specimen quality according to the standard.

Referring to the second dictum of the Health Minister's Decree, it is clear that a hospital that has been designated 
as a Covid-19 referral hospital is tasked with implementing covid handling services in Indonesia. In a circular letter from the Minister of Health of the Republic of Indonesia regarding the protocol for handling Covid-19 for public communication protocols, it was also stated that in handling disease outbreaks, communication is an important part of dealing with a pandemic. Public trust needs to be built and maintained so that there is no panic in the community and the handling can run smoothly. The government must show that the government is serious, ready and capable of handling this outbreak. Perceptions of the readiness and seriousness of the government need to be conveyed to the public through comprehensive and periodic explanations, by explaining what the government has done and will do.

The government has also issued health protocol arrangements that are regulated during the pandemic period at work, including regarding the sharing of existing human resources (employees) through working from work from home (partially or completely), taking temperature measurements with thermo gun and risk self-assessment. Covid-19, arranging work time is not too long which can cause a decrease in the body's immune system, requires the use of masks, regulates nutritional intake and also facilitates a safe and healthy work place including work environment hygiene and sanitation, hand washing facilities, physical distancing and also a clean and healthy lifestyle (PHBS)

In the midst of the seriousness of the government, the public and health actors in handling the increasing covid cases, in October 2020, compiled from the droneemprit.id data source, an issue arose that was a hot topic of conversation by the public and also netizens with the hashtag \#BongkarMafiaCovidRS.

\section{Kontroversi bermula dari omongan}

Droneemprit.id analyzes the issue under the title Hospital: between Covid-19 and accusations of many hospital mafia, and coviding patients. Droneemprit.id maps the analysis of hospital issues based on conversations that often appear on twitter. The controversy began with the statement byvHead of the Presidential Staff Office (KSP) Moeldoko who said that many hospitals defined patients as having died positive for Covid-19 even though they were negative. Moeldoko's requested that hospitals be honest with data on patient deaths amid the Covid-19 pandemic to prevent unrest in the community. This is based on the fact that the referral hospital covides all the patients who die to get a budget from the government. In addition to the statement from the KSP, the accusation against the Ibnu Sina Pekanbaru Islamic Hospital that has coviding a patient, has also emerged as an interesting conversation for netizens. It is assumed that Ibn Sina Islamic Hospital is taking advantage of the Covid-19 pandemic situation that is currently happening in Indonesia. But this has been denied by the deputy director of medical services Islam Ibn Sina Hospital Pekan Baru and declare that the patient is still in the status is suspect. He also explained the chronology of the patient $\mathrm{S}$ treatment / care until the patient was buried. The tweet about the hospital mafia coviding this patient was analyzed by droneemprit.id with the following trends and volumes:

The Yogyakarta Indonesian Doctors Association (IDI) replied that the accusation was painful for health workers because they had worked hard and were at the forefront of dealing with Covid-19. IDI Semarang also firmly denied Moeldoko's statement about the hospital that deliberately covided all the patients who died to get a budget from the government. Not to forget the chairman 


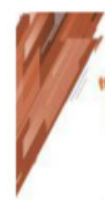$$
\text { but insit on bing truthe }
$$

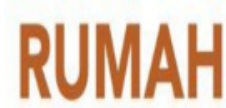
SAKIT

ANTARA COVID.19 DAN TUDINGAN BANYAK MAFIA RUMAH SAKIT, DAN MENGCOVIDKAN PASIEN

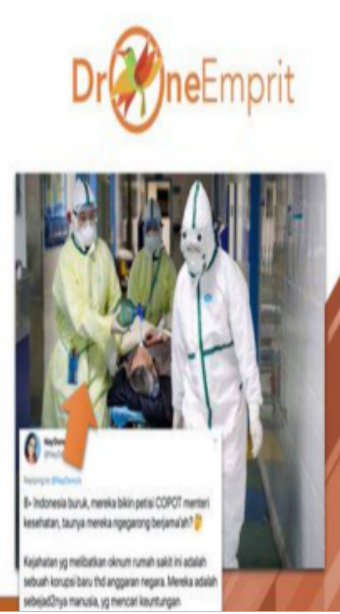

FIGURE 1. Narrative analysis of hospital issues and acusations to the hospital,

Source: (droneemprit.id,2020)

of the central IDI, Dr. Daeng Faqih, also responded to the statement. The Association of Indonesian Hospitals (PERSI), responding to the statement that it is not accompanied by facts, evidence or not proven true and this can build a false perception or lead to opinions as if the hospital is doing behavior that is not in accordance with the provisions or fraud / fraud. This misperception and opinion has resulted in misinformation and disinformation that is detrimental to hospital services in handling Covid-19. It is also feared that it will cause tremendous stigma and impact on decreasing public trust in hospitals. it can also undermine the enthusiasm and sincerity of the services carried out by hospitals and health workers

On the other hand, Indonesia Police Watch (IPW) also commented on the issue of value associated with the costs that must be borne by the government for one covid patient within 14 days of treatment with the assumption of Rp. 105 million (lowest cost), and Rp. 231 million for patients with complications. IPW even asked Bareskrim to investigate and audit all Covid-19 referral hospitals to find out how many victims actually died due to Covid-19 and how many patients were Covid-19.

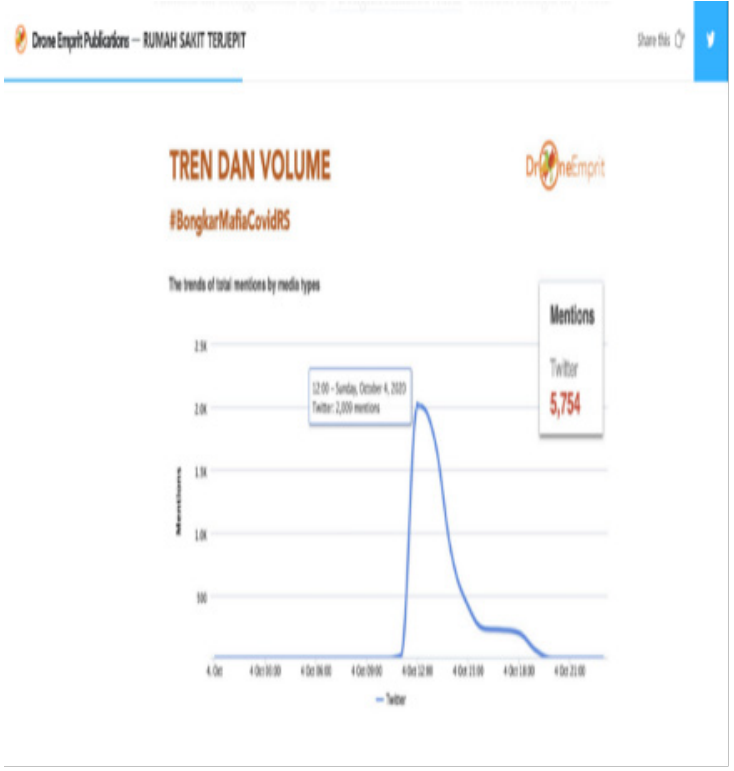

FIGURE 2. The trend and volume of the \#bongkarmafiacovidrs conversation

Source: (droneemprit.id, 2020)

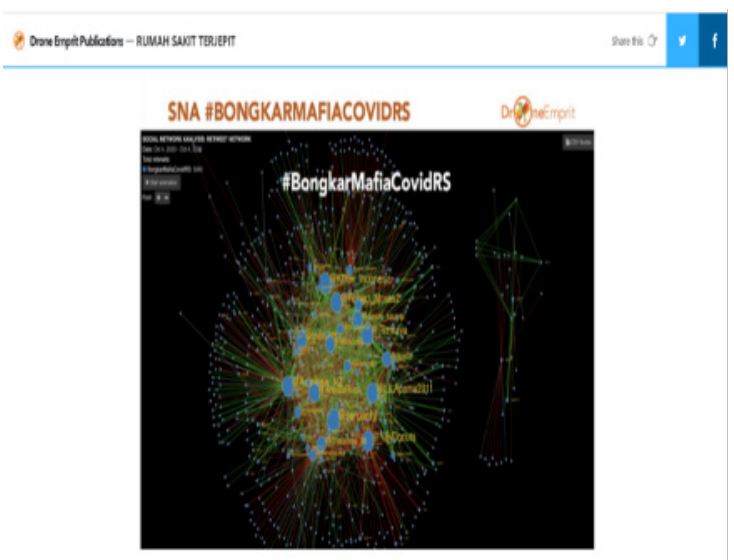

FIGURE 3. Citizen discussion traffic with \#bongkarmafiacovidrs

Source: (droneemprit.id,2020)

Comments from health actors also emerged. many think that Moeldoko's words are considered to belittle and underestimate the responsibility of hospitals or medical personnel in handling Covid-19 in Indonesia. Many doctors did not accept Moeldoko's accusations. On social media, doctors are busy delivering protests, such as protests from Dr. Berliana Idris via Twitter account@berlianidris “accusations that hospitals are coviding patients to get this budget is dangerous, let alone uttered by state officials". while Dr. Tonang through 
his account@tonangardyanto tweeted "Hard work to build trust, collapsed in an instant. do you realize sir? ". another account,@ dr_koko28 tweeted "Covidpatient? what's in it? How to? ckckck" and many more tweets from other health workers.

Judging from the data collected by droneemprit.id, there were 5,754 tweets with the hashtag \#BongkarMafiaCovidRS on Sunday 4 October 2020 and trending on that day (FIGURE 2). The narrative that emerged through several tweets that became top trending tweets, among others: The health mafia used the Covid-19 pandemic to reap benefits with references from Suara.com: Statement from IPW about the alleged health mafia and the

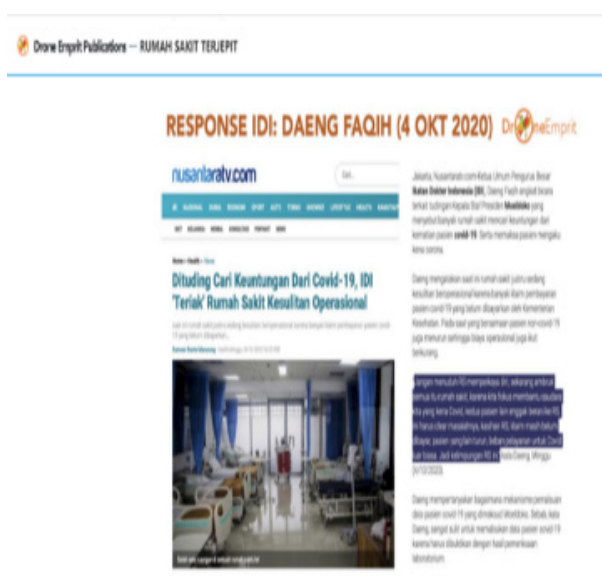

FIGURE 4. response from IDI regarding \#bongkarmafiacovidrs (1)

Source: (droneemprit.id, 2020)

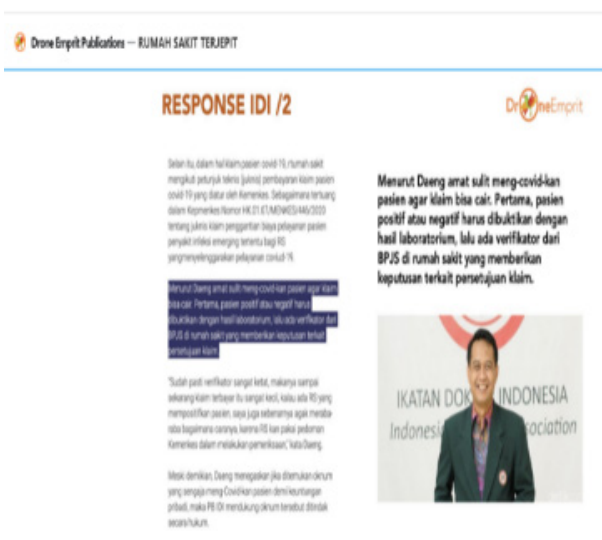

FIGURE 5. response from IDI regarding \#bongkarmafiacovidrs (2)

Sumber: (droneemprit.id,2020) statement of the head of the KSP while in Semarang, Some areas that allegedly taking advantage of the pandemic to increase budget requirements with references from source.com, Bantennews. co.id, Bisnis.com: IPW's statement about the alleged Covid-19 game by the hospital mafia, allegedly there is a rogue hospital for the sake of the corona budget in Ciamis, Pasuruan, Jambi and several other cities with references from Kompas TV: Banggar DPR, there are public reports in many WhatsApp groups, There are hospitals that testify sick people who are not actually infected with Covid, with references from Bisnis. com: IPW statement, Neta S Pane asks the Police Criminal Investigation Unit to dismantle RS mafia, Regarding the meeting between the head of the KSP and the Governor of Central Java, discussing "the hospital should not carelessly covided all patients who died during the pandemic "refer to data on the death of Covid-19 patients from each hospital and public unrest on WhatsApp, social media, with references from beritasatu.TV and bantennews.co.id: K SP in an interview at beritasatu and IPW Statement asking for Crime The National Police, the prosecutor's office and the Corruption Eradication Commission (KPK) dismantled the hospital mafia (FIGURE $6)$.

When studied and reviewing these issues and review of various media online as well as the policies of the government, especially the Ministry of Health of the Republic of Indonesia, related to the role of hospital and health personnel in the handling of the pandemic Covid-19, it can describe some points as follows : 1) Regarding the circulation of the hospital mafia issue related to the actions of hospitals that offer patients, this has been responded by the Indonesian Doctors Association (IDI) (FIGURE 4 and 5), the Association of Indonesian 
Hospitals (PERSI), the Indonesian National Nurses Association (PPNI), health workers, and also health observers and even the Minister of Health. From the responses given, it can be concluded that the accusation of this dishonorable act is baseless and there has been no official report by the patient (no clear facts). 2) Moeldoko's statement has undermined public trust in the hospital, offended the health workers who have fought against the Covid-19 pandemic. The hospital has a standard operating procedure (SOP) in handling covid-19 and all management activities for handling patients starting from admission, being treated and even death records entered into the patient's medical record. So if the hospital wants to determine covid status for patients who are not infected with Covid, this will be difficult to do. 3) In dealing with covid-19, the Central Government through the Minister of Health has designated 132 covid-19 referral hospitals. In Decree number HK.01.07 / Menkes / 275/2020 it is explained that to ensure continuity of health services in the context of overcoming certain emerging infectious diseases, a referral hospital is needed. The referral hospital is in charge
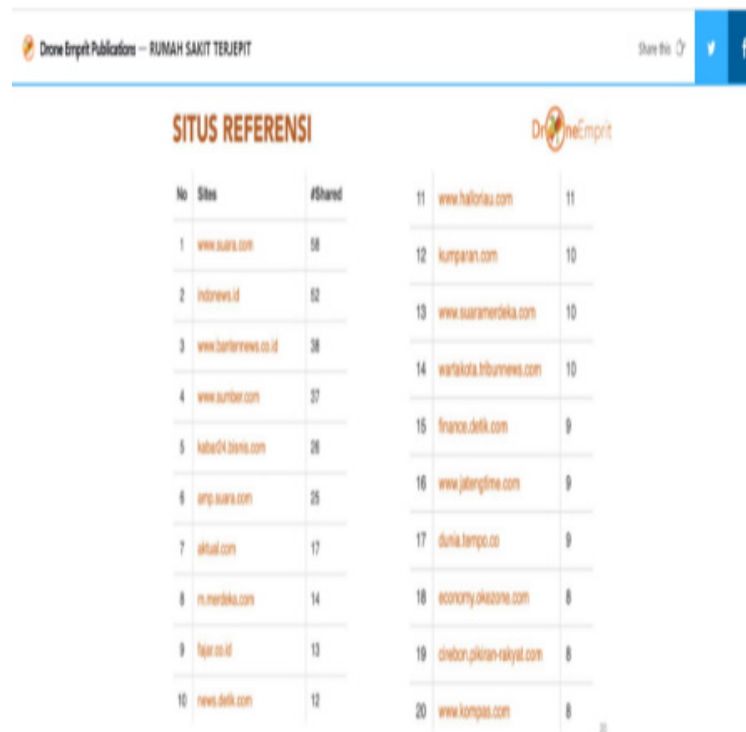

FIGURE 6. \#bongkarmafiacovidrs tweet reference site in the media Source: (droneemprit.id, 2020) of implementing referral health services including covid-19. 4) In addition to referral hospitals, other hospitals can also manage and provide referral health services for Covid-19 patients and specimens, until the determination of public health emergencies or covid-19 disasters is revoked. 5) Hospitals that provide health services for covid-19 patients will receive patient care costs in accordance with statutory provisions.

In the process of submitting claims for covid-19 patients, guidelines for submitting claims for hospitals have been published. It should be underlined that Covid-19 patients are not billed for treatment while in the hospital. Treatment costs are reimbursed by submitting a claim from the hospital to the Ministry of Health. Provisions regarding financing and claim procedures are contained in the Minister of Health's decision number HK.01.07 / Menkes / 446/2020 regarding technical instructions for claims for reimbursement of service fees for certain emerging infection disease patients for hospitals that provide Covid-19 services. There are stages in submitting payment claims which include administrative verification and verification of patient services.

Regarding the accusation that the hospital mafia has coviding patients to take advantage, of course this requires concrete evidence because submitting a patient's claim must pass detailed verification. The Chairman of the Association of Indonesian Hospitals (PERSI) emphasized that the hospital had followed the procedure for submitting claims for Covid-19 patients, so the news about hospitals finding patients was not true. Submission of claims for covid-19 patients is proven by clinical assessments, medical resumes, laboratory examinations and other supporting data and this has been stated in the Decree of the Minister of Health number HK.01.07 
/ Menkes / 446/2020.

If someone is asked by the hospital to sign an official report, this can be grouped into the customer communication education process. Why are BPJS patients after treatment either dead or recovered before going home given the option to sign? For example, if you want to sign, the costs for Covid-19 treatment at the hospital are free, but if you don't want to sign, then you are told to pay. According to Dr. Tonang's explanation in his account@tonangardyanto as stated in the kawalcovid19.id Instagram post, that this is part of the concept of patientfocused service. Patients and families are involved in the decision-making process for case management and care management. This is the importance of customer communication.

It was further explained that what was signed was the General Consent, which contained the consent of the patient and / or the patient's family, after receiving information from the hospital. This General Consent is done at the beginning of the treatment. For the Covid-19 case, it is carried out after an initial diagnosis (working diagnosis) is made as suspect or probable or if after being treated for several days there are symptoms or typical signs of Covid-19. before entering the isolation room, there was an explanation of infection as a process of educating customer-topatient communication. Sometimes this educational process through customer communication is often misunderstood by patients or the patient's family. Patients and their families feel persuaded, persuaded or even threatened to want to be "covided" so they don't have to pay, even though that is not what is meant. It all depends on the patient and family after receiving education from the hospital. If the patient or the patient's family refuses to take a medical action, the patient or the patient's family has the right to refuse and not to sign the consent form or what is often referred to as general consent. This customer communication is important. In addition to providing a sense of security, knowledge of what actions to take and also trust in the executor of the action, this communication will also prevent medical personnel from getting treatment or lawsuits and being able to act safely and comfortably because the communication message conveyed is well received by the patient. or the patient's family.

The following is an official rebuttal by the Association of Indonesian Hospitals (PERSI), which essentially emphasizes that the issue of coviding patients is an issue that is not based on facts and the hospital has an SOP for handling Covid-19:

The Center for Indonesia's Strategic Development Initiatives (CISDI) Research Analysis Study has also made discussions related to accusations of this issue. Experts emphasize that coviding patients requires serious conspiratorial action because it violates ethical health laws.

In accordance with the Law of the Republic of Indonesia number 44 of 2009 concerning Hospitals where the hospital is a health service institution for the community with its own characteristics that are influenced by developments in health science, technological advances and socio-economic people who must continue to be able to improve services that are of higher quality and affordable by the community in order to realize the highest degree of health, a hospital is obliged to provide complete health services to the community. In providing Covid-19 patient services, the hospital has guidelines based on the Minister of Health's Letter number HK.01.07 / Menkes / 413/2020 regarding guidelines for the prevention and control of Corona Virus desease 2019 (Covid-19). Given that Covid-19 is a type of disease that 
causes public health emergencies as well as non-natural disasters that not only cause death but also cause considerable economic losses, Covid-19 is treated specifically considering that the antidote for drugs and vaccines has not been clearly found. This guideline applies to all hospitals in Indonesia, both governmentowned and private hospitals.

Responding to the accusation against this hospital mafia, refer from dr. Tonang through his account@tonangardyanto: "Hard work to build trust, collapsed in an instant. do you realize Sir?", as if to emphasize the importance of the trust built so far, collapsed in an instant through

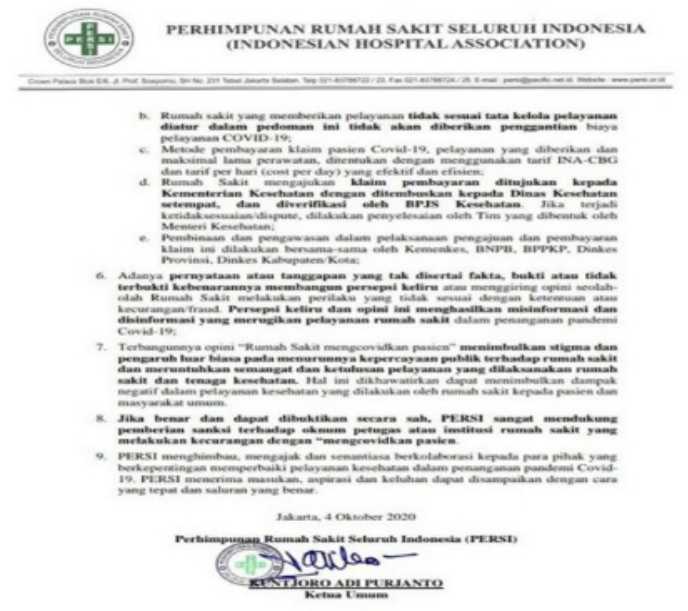

FIGURE 7. PERSI's public statement regarding the accusation that the hospital coviding patient (p.1)

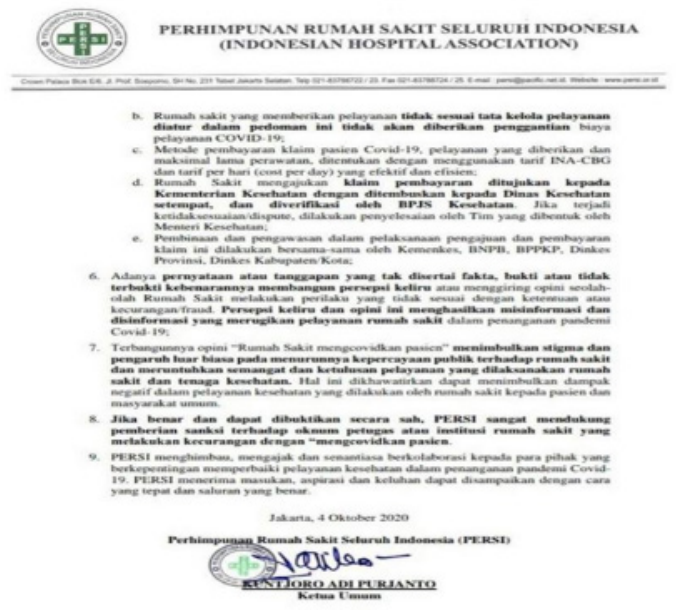

FIGURE 8. PERSI's public statement regarding the accusation that the hospital coviding patient (p.2) (Sintesanews.com, 2020) baseless accusations. This is certainly reasonable for people in the field to put forward, as if they have worked hard with clear instructions and in accordance with procedures, but are still accused of doing things that are not in accordance with the procedure. Of course this has an impact on the image of the hospital.

A positive image for an institution such as a hospital is an important thing that needs to be maintained, because the hospital is a public facility for the community to obtain health services. A hospital that does not have an image

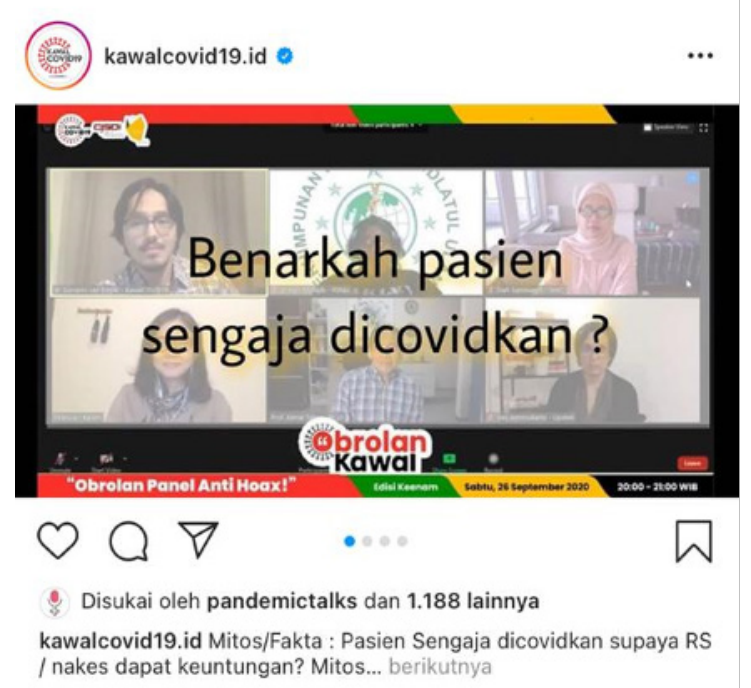

FIGURE 9. study related to the accusation of coviding patients with health community and observers (Instagram@kawalcovid19. $i d, 2020)$

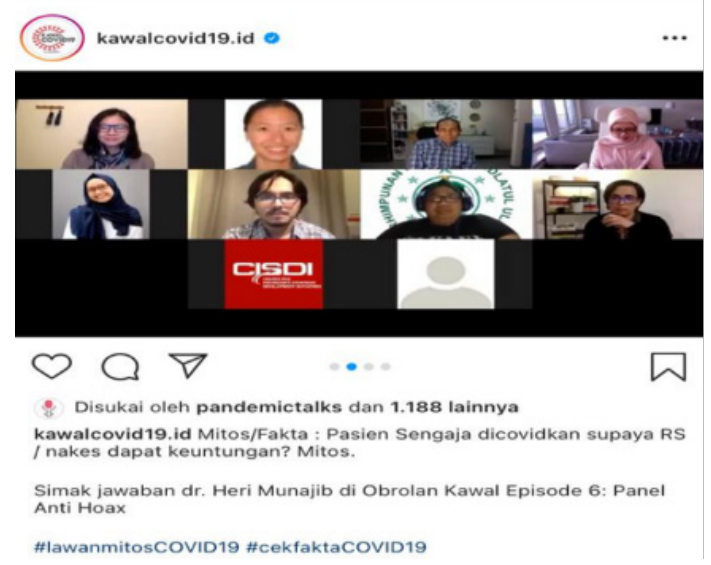

FIGURE 10. CISDI study of coviding patiens.(Instagram@kawalcovid19.id,2020) 
and is not trusted by the public will, of course, experience setbacks and even bankruptcy. For this reason, the hospital has a public relations division which has the task of assisting the hospital in building the image of the hospital organization. A good image will be very beneficial for the marketing of the hospital services concerned. Hospitals cannot live without public support, because with public support, organizational success is easier to achieve. One way to maintain and improve the image of the hospital is by implementing customer communication, the customers referred to here are patients, patient families, visitors, the surrounding community and also employees of the hospital.

Issues have become a dynamic in organizational life. Issues that appears can be both good issues and sometimes as bad issues. A bad issue, if not handled properly through proper issue management, will cause a crisis in the organization. The issue will develop into a rumor that can spread widely in the community and create a bad image for the company. However, if the right steps are taken to handle developing issues, then these issues can become an opportunity for the organization to develop more.

Referring to the issue of accusations that the hospital has coviding patients, it is necessary to know that in patient care in the hospital, a doctor or nurse conducts customer communication or legal communication by providing an explanation regarding the patient handling procedure to be taken and also filling out medical approval if someone the patient wants to do a medical action by the family. This means that the patient's family will know what type of action will be applied to the patient. This is important to do to prevent lawsuits against the hospital for the actions taken. The family has the right to approve or reject the action if the family does not want it. Dartina (2018) states that persuasive communication is very important to retain customers so that customers can know the importance of an action procedure to be carried out. Wardhana (2015) also states that service quality and customer relationship management will have a partial and significant effect on customer value. This means that if the relationship between the service provider (in this case the hospital) and the service recipient (customer) is well established, the value of the service will be of high quality and the satisfaction of both parties will be fulfilled. Customers can be served excellently by integrating a well-ordered service marketing mix and customer relationship management which will increase customer loyalty (Agustini, 2007).

Reflecting on the foregoing, efforts to test a patient if indeed the patient is not sick with Covid-19, is something that is difficult to do, considering that to establish the diagnosis of someone who has Covid-19 or not, there must be procedures carried out such as laboratory examinations. through a rapid test or swab. The patient's family will definitely be notified if this action will be carried out.

Covid-19 has indeed become a reality of a disease that changes the social structure of society. Social behavior changes, so does social cohesion. Usage, habits, behavior, and customs also adapt. The health community needs clear information in dealing with this Covid-19 pandemic. Therefore, health communication must be applied to understand health information and services together, both by health actors, the general public and observers of the world of health. Hoaxes must be fought so that people's needs for health information and services are fully obtained. Health communication during a pandemic has a problem with a lot of information coming and it is difficult to contain. There was 


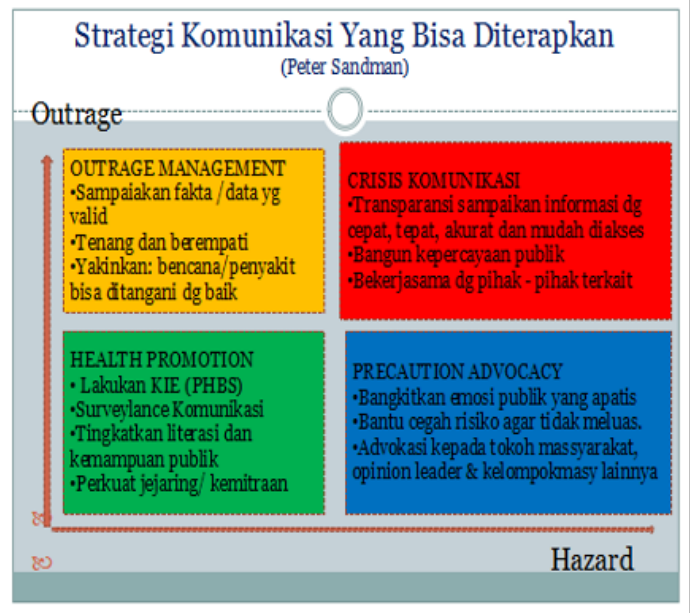

FIGURE 11. Communication strategy to customers

a lot of noise in the news and in the beginning the government wasn't ready to counter it. Everyone talks about health from just forwarding the message to even adding to the message and some are incompetent especially in the media of friendship like WA Group which can add to the problem. Everyone suddenly wanted to talk and become "experts" at the problem. In communicating, a communicator should know who he is, who are the opponents he invites to communicate and also understand good communication science.

Effendy, quoting Hovland in his book Science, Theory and Philosophy of Communication, states that the science of communication is a systematic effort to formulate in exactly the right way the principles of information transmission and the formation of opinions and attitudes (2003: 13). Hovland pointed out that what is used as the object of communication science study is not only the way of conveying information, but also the formation of public opinions and attitudes (public attitudes). Mulyana citing Miller in his book An Introduction to Communication Studies say that communication as $\mathrm{s}$ state all-situations that possible a source transmitting a message to a recipient with the recipient's behavior constituted to influence (2002: 54). Miller also stated that in communication there is the delivery of messages which can influence the behavior of the recipient of the message. So that what happens in a communication process is a message delivery influencing the behavior of the message recipient. Hidayat citing Berelson and Steiner in his book Ethics and the Press Law states that communication include all the procedures through which a person's mind can affect others. Communication is the process of exchanging information and feelings between two or more people, and is important for effective management (2003: 3). The occurrence of communication is a consequence of social relations (social relations).

Within

the hospital management itself, sometimes various communication problems arise with colleagues who are assigned to functional services and in structural management. With so many changes in disease progression that can be every day or even minute, sometimes causing noise in the hospital itself. Statements that arise as a result of miscommunication must be deflected and straightened out by health communicators quickly and precisely and by competent people, because talking about health is the property of all circles and the medical community is currently needed in the field as the spearhead in services as well as the delivery of accurate information, careful and precise according to his knowledge to the community. And speaking of health, we must collaborate not to blame a situation and eliminate the selfishness of each one to be able to work together to fight the pandemic.

Speaking of health belongs to all fields of science from their respective scientific point of view. From the perspective of crisis communication, communication patterns, especially for state officials, should become learning 
materials for every state actor to improve their communicative competence in disseminating information to the public. Meanwhile, doctors / nurses or all elements of health as health communicators in times of public health emergencies such as today are by offering health information needed by the public and fighting dangerous behavior including wrong information so as not to cause infodemic information in the community. Issues that spread must be handle wisely, such as the issue of coviding patient. Through the implementation of good customer communication between doctors / nurses and patients / patients' families, the negative issue about coviding patients can be handled because there is a relationship of understanding between service providers and their customers.

\section{CONCLUSION}

The Indonesian people who are currently being hit by the Covid-19 outbreak continue to need information about health, especially regarding the handling and development of Covid-19 in Indonesia. The delivery of inaccurate information can cause uproar in the community, such as the emergence of the issue of the hospital mafia coviding patients. Various comments came from various circles. Health actors, especially health workers who work directly and deal with Covid-19 patients, also contributed to contributing sharp comments to the spreaders of the issue.

Many parties regret that the emergence of this issue came out of a state actor, and it has had a tremendous impact on health workers in hospitals who have worked hard and struggled in this covid-19 delivery. Rebuttals also emerged from high-ranking health professional organizations such as IDI, PERSI, PPNI and even the Indonesian Minister of Health. Good communication is needed in conveying information to the wider community. Because the information conveyed is based on facts, it will be easier to find the truth than things that are not facts. In warding off the issue of the hospital coviding this patient, the hospital has implemented customer communication which is intended to establish communication so that there is no misunderstanding between service providers and consumers. Customer communication is also intended to give a good education to patients and families of patients that did not happen misunderstanding delivered both parties, it is believed to be able to maintain the image of the hospital on this issue.

From the literature study above, it can be said that the issue of accusations related to hospitals that coviding patients is something that is not based on facts (there is no evidence based to support this issue). Dividing patients is something that is difficult to do because hospitals in providing Covid-19 services already have guidelines and technical instructions on how to perform procedures for the management of Covid-19 patients. The image of the hospital can also be well preserved through the implementation of effective customer communication between doctors / nurses with patients and their families so that a clear understanding is created regarding the patient's condition.

\section{REFERENCE}

Asnawi A.A, Awang Z, Mohammad M, Karim F. (2019). The Influence of hospital image and service quality on patients' satisfaction and loyalti. Management Science Letters, 911-920

Andri, Saubani, Laeny Sulistyawati. (2020). Isu RS mengcovidkan pasien, PPNI: sulit dilakukan. Diambil dari https:// republika.co.id/berita/qhsba9409/isurs-mengcovidkan-pasien-ppni-sulitdilakukan. Diakses 5 Nopember 2020

Agustini, Prima Mulyasari. (2007). 
Membangun Loyalitas Pelanggan Citilink Garuda: Tinjauan Manajemen Hubungan Pelanggan. Mediator Vol 8 No.2, 297-312

Azizah, Nur, (2020). PERSI tegaskan pengajuan Klaim oleh $R S$ terkait Pasien Covid-19 sesuai aturan. Diambil dari https://www.medcom. id/nasional/peristiwa/ob33Jyyb-persitegaskan-pengajuan-klaim-oleh-rsterkait-pasien-covid-19-sesuai-atura. Diakses 7 Nopember 2020

Bayhaqi, Yuzza. (2006). Analisis Pengaruh Kualitas Layanan dan Keunggulan Produk terhadap kepauasan pelanggan dan dampaknya pada minat membeli ulang.

Bayu, hermawan, Nawir arsyad. (2020). Menteri Terawan komentari tudingan mengcovidkan pasien. Diambil dari https://republika. co.id/berita/qiihya354/menteriterawan-komentari-tudingan-rsmengcovidkan-pasien. Diakses 5 Nopember 2020

Biro Hukum dan Organisasikemenkes, (2020). KepMen Tentang Protokol Kesehatan Bagi Masyarakatditempat danfasilitas Umum dalam rangka pencegahan dan pengendalian Covid-19. Diambil dari http://hukor.kemkes.go.id/ uploads/produk_hukum/KMK_No_ HK_01_07-MENKES-382_2020_ ttg_Protokol_Kesehatan_Bagi_ Masyarakat_di_Tempat_dan_ Fasilitas_Umum_Dalam_Rangka_ Pencegahan_COVID-19.pdf. Diakses 6 Nopember 2020

Biro hukum dan organisasi Kemenkes, (2020). Penetapan Rumah Sakit Rujukan Penanggulangan Penyakit Infeksi Emerging Tertentu. Diambil dari http:// hukor.kemkes.go.id/uploads/produk hukum/KMK_No_HK_01_07MENKES-275_2020_ttg_Penetapan RS_Rujukan_Penanggulangan_ Penyakit_Infeksi_Emerging_Tertentu. pdf. Diakses 7 Nopember 2020

Chao Can Wu, (2011). The impact of hospital brand image on service quality, patient satisfaction and loyalti. African journal of busines management

Darlina, Deli, (2015). Pengaruh Citra Perusahaan dan Kualitas Pelayanan terhadap Loyalitas Pelanggan terhadap Loyalitas Pelanggan pada Jasa Perhotelan JOM FISIP Vol.1 No.3

Dartina, Vina. (2018). Strategi Komunikasi Persuasi Sales and Account Manager Dalam Mempertahankan Pelanggan. IDEA Jurnal Humaniora Vol 1 No.1, 109-121

Direktorat Jenderal Pencegahan dan Pengendalian Penyakit Kemenkes, (2020). Diambil dari Covid19.kemkes. go.id/suratedaran menteri kesehatan nomor 215 tahun 2020. Diakses 7 Nopember 2020

Effendy, Onong Uchjana. (2003). Ilmu, teori dan filsafat komunikasi. Bandung: Citra Aditya Bakti

Ervan, Bayu Setianto,(2020). Heboh Tudingan Pejabat Istana Soal Rumah Sakit "Mengcovidkan" Pasien. Diambil dari https://era.id/nasional/39681/hebohtudingan-pejabat-istana-soal-rumahsakit-mengcovidkan-pasien. Diakses 6 Nopember 2020

Fahmi, Ismail, (2020). Rumah Sakit, Antara COVID-19 dan tudingan banyak mafia rumah sakit, dan mengcovidkan pasien. Diambil dari https://pers. droneemprit.id/rumah-sakit-terjepit/. Diakses 5 Nopember 2020

Fikhi Handayani, (2015). Peranan humas dalam meningkatkan citra rumah sakit kusta dr Tadjudin chalid makasar, universitas Hasanudin

Gisela Sharon L, Budi Santoso S, (2017). Analisis pengaruh kualitas layanan, fasilitas, citra rumah sakit, kepuasan pasien dalam rangka meningkatkan loyalitas pasien, Diponegoro Journal of Management, Vol.6, 355-366

Garjito, Dany. (2020). Diterpa Isu Mengcovidkan Pasien, Rumah Sakit Beri Penjelasan. Diambil dari https://www.suara.com/ news/2020/10/08/062711/diterpa-isu- 
mengcovidkan-pasien-rumah-sakitberi-penjelasan. Diakses 3 Desember 2020

Haffizurrachman, (2004). Kepuasan Pasien dan Kunjungan Rumah Sakit”, Jurnal Kesehatan Masyarakat nasional, Vol. 4, No.1, hh. 10- 17

Hanevi Djasri, Fakultas Kedokteran Universitas Gajah Mada, (2020), The Journal of Hospital Accreditation, Corona Virus dan Manajemen Mutu Pelayanan di Rumah Sakit,

Hadi Mulyono, Dany Garjito. (2020). Diterpa Isu Mengcovidkan Pasien, Rumah Sakit Beri Penjelasan. Diambil dari https://www.suara.com/ news/2020/10/08/062711/diterpa-isumengcovidkan-pasien-rumah-sakitberi-penjelasan?page $=$ all. Diakses 5 Nopember 2020

Herlambang, Adib Auliawan, (2020). Pejelasan IDI Semarang soal Rumah Sakit sengaja mengcovidkan pasien. Diambil dari https:// $\mathrm{w} \mathrm{w} \mathrm{w}$. a y o s e m a r a n g. c o m / $\mathrm{read} / 2020 / 10 / 07 / 64931 /$ penjelasanidi-semarang-soal-rumah-sakitsengaja-mengcovidkan-pasien. Diakses 6 Nopember 2020

Heriani, Fitri Novia, (2020). Begini Mekanisme Pengajuan dan Penetapan PSBB Suatu wilayah. https://www. hukumonline.com/berita/baca/ 1t5e8ee2a568829/begini-mekanismepengajuan-dan-penetapan-psbb-suatuwilayah/. Diakses 6 Nopember 2020

Humas, Satgas Covid19, (2020). Surat Edaran Menteri PANRB Repubik Indonesia nomor 46 tahun 2020 tentang Pembatasan Kegiatan Mudik. Diambil dari https://covid19.go.id/p/ regulasi/se-menpan-rb-nomor-46tahun-2020. Diakses 6 Nopember 2020

Humas, Kemenhub, (2020). Peraturan Menteri Perhubungan Republik Indonesia Nomor PM 25 Tahun 2020. Diambil dari http://jdih.dephub.go.id/index. php/produk_hukum/view/VUUwZ01qVWdWRUZJVIU0Z01qQXINQT09. Diakses 6 Nopember 2020
Hidajahningtyas, Nurullah, Andi Sularso dan Imam Suroso, (2013), "Pengaruh Citra, Kualitas Layanan Dan Kepuasan Terhadap Loyalitas Pasien Di Poliklinik Eksekutif Rumah Sakit Daerah Dr. Soebandi Kabupaten Jember", Jurnal Ekonomi Akuntansi dan Manajemen (JEAM), Vol. 12. No. 1.

Hafied, Cangara. (2010). Pengantar Ilmu Komunikasi. Jakarta: PT Raja Grafindo

Haffizurrachman. (2004). Mengukur kepuasan suatu institusi kesehatan. Majalah Kedokteran Indonesia. Volume 54. Nomor 7.283 - 288.

Hidayat, Dedy.N. (2003). Etika dan Hukum Pers. Jakarta

Instagram : kawalcovid19.id

Instagram : pandemictalks

Istijanto, (2005).Aplikasi Praktis Riset Pemasaran. Jakarta : PT Gramedia Pustaka Utama

Keputusan Menteri Kesehatan nomor HK.01.07/Menkes/382/2020 tentang Protokol Kesehatan bagi masyarakat di tempat umum dan Fasilitas umum dalam rangka pencegahan dan pengendalian Covid-19

Keputusan Menteri Kesehatan nomor HK.0 1.07/MENKES/275/2020 tertanggal 23 April 2020 tentang penetapan rumah sakit rujukan penanggulangan penyakit infeksi emerging tertentu

Keputusan Menteri Kesehatan nomor HK.01.07/Menkes/446/2020 tentang petunjuk teknis klaim pengantian biaya pelayanan pasien penyakit infeksi emerging tertentu bagi rumah sakit yang menyelenggarakan pelayanan Covid-19

Keputusan Menteri Kesehatan nomor HK. $01.07 /$ Menkes/4 $13 / 2020$ tentang pedoman pencegahan dan pengendalian Corona Virus disease 2019 (Covid-19)

Kotler, Philip, (1996). Manajemen Pemasaran. Jakarta : Salemba Empat

Komalawati, Veronika,. (2002). Peranan Informed Concent dalam transaksi terapeutik: Persetujuan dalam hubungan Dokter dan Pasien, Suatu tinjauan yuridis. Bandung: Citra 
Aditya Bakti

Lumentana, B. (1989). Pelayanan medis, Citra, Konflik dan harapan. Yogyakarta: Kanisius

Lubis A, Lumbanraja P, Hasibuan B.Lubis R, European Reasearch Studies Journal, (2017), A study of service quality, corporate social responsibility, hospital image and hospital value creation in medan

Mohd Isa S, Lim G.S.S, Chin P.N, (2019), Patients' intent to revisit with trust as the mediating role: lesson from penang malaysia,

Muchis M, Dewanto A, (2011), Pengaruh kepercayaan, kepuasan pelanggan dan komitmen hubungan terhadap citra rumah sakit di Blitar

Mulyana, Deddy. (2002). Ilmu Komunikasi : Suatu Pengantar. Bandung : Remaja Rosda Karya

Moeleong, Lexy J. (2008). Metode penelitian Kualitatif. Bandung: Remaja Rosdakarya

Peraturan Menteri Kesehatan Nomor 9 Tahun 2020 tertanggal 3 April 2020 tentang Program Pembatasan Sosial Berskala Besar (PSBB)

Peraturan pemerintah (PP) nomor 21 tahun 2020 tentang Pembatasan Sosial Berskala Besar

Porter, S.S. and Claycomb, C. (1997). Journal of Product and Brand Management, The Influence of Brand Recognition on Retail Store Image

Ramli A.H, (2019), Patient satisfaction, Hospital image and patient loyalti in west province

Setkab, Humas. (2020). Inilah PP PSBB untuk Percepatan Penanganan Covid-19. Diambil dari https://setkab.go.id/ inilah-pp-pembatasan-sosial-berskalabesar-untuk-percepatan-penanganancovid-19/. Diakses 6 Npember 2020

Sugiyono, (2014). Memahami Penelitian Kualitatif. Bandung: Alfabeta

Tim Detik, (2020). Saat IDI hingga
Pemda jawab Moeldoko Soal Isi RS Covid-kan Pasien. Diambil dari https://news.detik.com/berita-jawatengah/d-5201392/saat-idi-hinggapemda-jawab-moeldoko-soal-isu-rscovid-kan-pasien. Diakses 5 Nopember 2020

Undang Undang nomor 44 tahun 2009 tentang Rumah Sakit

Wardhana, Aditya. (2015), Determinan Nilai Pelanggan dan Implikasinya Pada Dependensi Pelanggan Bengkel SUV Premium. MIMBAR Vol 31 No.1, 3140

Wedhasary, Inggried Dwi. Dewi, Retia Kartika, (2020). Cara Pengajuan Klaim Penggantian Biaya Pasien Covid-19 https://www.kompas.com/ tren/read/2020/07/25/150300065/carapengajuan-klaim-penggantian-biayapasien-covid-19?page=all. Diakses 7 Nopember 2020

WHO, Director General, (2020). Opening remarks media breaving on Covid19. Diambil dari https://www.who.int/ $\mathrm{dg} /$ speeches/detail/who-directorgeneral-s-opening-remarks-at-themedia-briefing-on-covid-19---11march-2020. Diakses 5 Nopember 2020

Wicaksono, (2020). Moeldoko: Jangan semua pasien meninggal di vonis Covid-19. Diambil dari https://beritamedia. id/2020/10/moeldoko-jangan-semuapasien-meninggal-divonis-covid-19/. Diakses 5 Nopember 2020

Wibowo, Agus. (2020). Jubir Pemerintah : Atasi COVID-19 dengan Putus Rantai Penularan. Diambil dari https://covid19.go.id/p/berita/jubirpemerintah-atasi-covid-19-denganputus-rantai-penularan. Diakses 6 Nopember 2020

Wu, CC, (2011), "The Impact of Hospital Brand Image on Service quality, Patient Satisfaction and Loyalty", African Journal of Business Management, Bol. 5, No. 12 , hh. 4873-4882 